Research Article

\title{
In vivo chemotherapeutic insight of a novel isocoumarin (3-hexyl-5,7-dimethoxy-isochromen-1-one): Genotoxicity, cell death induction, leukometry and phagocytic evaluation
}

Flávio Henrique Souza de Araújo ${ }^{1,2 \dagger}$, Débora Rojas de Figueiredo $^{2 \dagger}$, Sarah Alves Auharek ${ }^{3}$, João Renato Pesarini $^{1,4}$, Alisson Meza ${ }^{5}$, Roberto da Silva Gomes ${ }^{6}$, Antônio Carlos Duenhas Monreal ${ }^{2}$, Andréia Conceição Milan Brochado Antoniolli-Silva ${ }^{1,4}$, Dênis Pires de Lima ${ }^{5,2}$, Candida Aparecida Leite Kassuya ${ }^{7}$, Adilson Beatriz $^{5,2}$ and Rodrigo Juliano Oliveira ${ }^{1,2,4,8}$

${ }^{1}$ Centro de Estudos em Célula Tronco, Terapia Celular e Genética Toxicológica, Hospital Universitário "Maria Aparecida Pedrossian", Empresa Brasileira de Serviços Hospitalares, Campo Grande, MS, Brazil.

${ }^{2}$ Programa de Mestrado em Farmácia, Centro de Ciências Biológicas e da Saúde, Universidade Federal de Mato Grosso do Sul, Campo Grande, MS, Brazil.

${ }^{3}$ Faculdade de Medicina do Mucuri, Universidade Federal dos Vales do Jequitinhonha e Mucuri, Minas Gerais, MG, Brazil.

${ }^{4}$ Programa de Pós-graduação em Saúde e Desenvolvimento na Região Centro-Oeste, Faculdade de Medicina "Dr. Hélio Mandetta", Universidade Federal de Mato Grosso do Sul, Campo Grande, MS, Brazil.

${ }^{5}$ Instituto de Química, Universidade Federal de Mato Grosso do Sul, Campo Grande, MS, Brazil.

${ }^{6}$ Faculdade de Ciências Exatas e Tecnologias, Universidade Federal da Grande Dourados, Dourados, MS, Brazil.

${ }^{7}$ Faculdade de Ciências da Saúde, Universidade Federal da Grande Dourados, Dourados, MS, Brazil. ${ }^{8}$ Programa de Pós-graduação em Genética e Biologia Molecular, Centro de Ciências Biológicas,

Universidade Estadual de Londrina, Londrina, PR, Brazil.

\begin{abstract}
Chemotherapy is one of the major approaches for the treatment of cancer. Therefore, the development of new chemotherapy drugs is an important aspect of medicinal chemistry. Chemotherapeutic agents include isocoumarins, which are privileged structures with potential antitumoral activity. Herein, a new 3-substituted isocoumarin was synthesized from 2-iodo-3,5-dimethoxy-benzoic acid and oct-1-yne in a cross-coupling Sonogashira reaction followed by a copper iodide-catalyzed intramolecular cyclization as key step using $\mathrm{MeOH} / \mathrm{Et}_{3} \mathrm{~N}$ as the solvent system. The present study also evaluated the leukometry, phagocytic activity, genotoxic potential and cell death induction of three different doses $(5 \mathrm{mg} / \mathrm{kg}, 10 \mathrm{mg} / \mathrm{kg}$ and $20 \mathrm{mg} / \mathrm{kg}$ ) of this newly synthesized isocoumarin, alone and in combination with the commercial chemotherapeutic agents cyclophosphamide $(100 \mathrm{mg} / \mathrm{kg})$ and cisplatin $(6 \mathrm{mg} / \mathrm{kg})$ in male Swiss mice. The results suggest that the isocoumarin has genotoxicity and causes cell death. Noteworthy, this new compound can increase splenic phagocytosis and lymphocyte frequency, which are related to immunomodulatory activity. When combined with either cyclophosphamide or cisplatin, chemopreventive activity led to a reduction in the effects of both chemotherapeutic drugs. Thus, the new isocoumarin is not a candidate for chemotherapeutic adjuvant in treatments using cyclophosphamide or cisplatin. Nevertheless, the compound itself is an important prototype for the development of new antitumor drugs.
\end{abstract}

Keywords: isocoumarin synthesis, genotoxicity, splenic phagocytosis, chemotherapy.

Received: November 23, 2016; Accepted: March 2, 2017.

Send correspondence to Rodrigo Juliano Oliveira. Medicine College, Federal University of Mato Grosso do Sul. Cidade Universitária, S/N. 79070-900 Campo Grande, MS, Brazil. E-mail: rodrigo.oliveira@ufms.br.

${ }^{\dagger}$ These authors contribute equally to this work
Introduction

The search for phenolic products with the potential to treat or cure cancer and/or to potentiate the cytotoxic effects of chemotherapeutic agents without having adverse 
effects on non-tumor cells is extremely important for the development of new chemotherapy drugs.

According to Pal et al. (2011) isocoumarins are characterized by a six membered heterocycle containing an oxygen atom in an unsaturated lactone, and represent an important group of natural products. They are useful intermediates in the synthesis of several hetero-carbocyclic compounds, including aromatic lactones called coumarins, which have an inverted lactone ring.

This class of compounds is known to have antiinflammatory, antioxidant (Paya et al., 1994; Murakami et al., 2000; Agata et al., 2004), apoptotic and anticarcinogenic potential (Paya et al., 1994; Agata et al., 2004; Chen et al., 2007).

Recent studies have shown that isocoumarins induced the formation of reactive oxygen species (ROS), activated p53 signaling and enhanced apoptosis (Yin et al., 2001). These characteristics are of interest for potential pharmaceutical applications (Yin et al., 2001; Agata et al., 2004; Chen et al., 2007).

Several compounds can prevent cancer via their antigenotoxic action, or even treat tumors by causing extensive DNA damage, leading to apoptosis (Liu et al., 2001; Fedel-Miyasato et al., 2014; Mauro et al., 2014). Thus, genotoxic and cell death assays, and tests that assess splenic phagocytosis and leukometry are widely used for initial assessment in the development of new drugs (Navarro et al., 2014; Carvalho et al., 2015). The present study describes the synthesis of a new isocoumarin, its toxicogenetic and cell death potential and its capability to alter splenic phagocytosis and leukometry alone and in combination with the chemotherapeutic agent cyclophosphamide and cisplatin in male Swiss mice.

\section{Material and Methods}

\section{Chemistry}

All reagents and spectrograde solvents for synthesis and nuclear magnetic resonance (NMR) measurements were purchased commercially and used without further purification.

\section{NMR measurements}

${ }^{1} \mathrm{H},{ }^{13} \mathrm{C}$ NMR and DEPT- 135 spectra were recorded at room temperature on a Bruker 300 spectrometer (Institute of Chemistry, UFMS, Campo Grande, MS, Brazil) (10\% in $\mathrm{CDCl}_{3}$ solutions at $298 \mathrm{~K}$ ) operating at 300.132 and 75.476 $\mathrm{MHz}$, respectively. Data processing was carried out on a Solaris workstation. The ${ }^{1} \mathrm{H}$ and ${ }^{13} \mathrm{C}$ chemical shifts are given on the $\delta$ scale (ppm) and were referenced to internal tetra-methyl-silane (TMS); coupling constants $(J)$ are reported in hertz $(\mathrm{Hz})$. The abbreviations $\mathrm{s}, \mathrm{d}, \mathrm{m}$ and quint were used for simplet, douplet, multiplet and quintet, respectively.

\section{Synthesis of compounds}

2-iodo-3,5-dimethoxybenzoic acid (compound 2 in Figure 1): A mixture of 3,5-dimethoxybenzoic acid (200 $\mathrm{mg}, 1.0 \mathrm{mmol}$ ) and $N$-iodosuccinimide (NIS) (230 mg, 1.0 $\mathrm{mmol})$ in the presence of $\mathrm{CF}_{3} \mathrm{CO}_{2} \mathrm{H}(0.025 \mathrm{~mL}, 0.3 \mathrm{mmol})$ in acetonitrile $(10 \mathrm{~mL})$ was stirred under reflux for $8.5 \mathrm{~h}$. After extraction with AcOEt $(315 \mathrm{~mL})$, the combined organic layers were washed with distilled water $(315 \mathrm{~mL})$ and brine $(315 \mathrm{~mL})$, and dried over $\mathrm{Na}_{2} \mathrm{SO}_{4}$. The solvent was evaporated under reduced pressure and the product was purified by chromatographic column (hexane/AcOEt, 7:3) to achieve the pure compound in $79 \%$ yield.

${ }^{1} \mathrm{H} \mathrm{NMR}\left(300 \mathrm{MHz}, \mathrm{CDCl}_{3}\right): \delta(\mathrm{ppm}) 6.98(\mathrm{~d}, J=2.7$ $\mathrm{Hz}, 1 \mathrm{H}), 6.55(\mathrm{~d}, J=2.7 \mathrm{~Hz}, 1 \mathrm{H}), 3.87(\mathrm{~s}, 3 \mathrm{H}), 3.83(\mathrm{~s}, 3 \mathrm{H})$.

3-hexyl-5,7-dimethoxy-isochromen-1-one (compound 3 in Figure 1): $\mathrm{CuI}(13.50 \mathrm{mg}, 0.07 \mathrm{mmol})$ and $\left(\mathrm{Ph}_{3} \mathrm{P}\right)_{2} \mathrm{PdCl}_{2}(25.20 \mathrm{mg}, 0.07 \mathrm{mmol})$ were added to a solution containing compound $2(57.9 \mathrm{mg}, 0.18 \mathrm{mmol})$ in 5.1 $\mathrm{mL}$ of trimethylamine and $5.0 \mathrm{~mL}$ of ethanol (freshly distilled and treated overnight with $\mathrm{KOH}$ and $\mathrm{CaH}_{2}$ ) and stirred for $30 \mathrm{~min}$. Subsequently, 1-octyne $(0.03 \mathrm{~mL}, 0.20$ mmol) was added and the reaction mixture was stirred at $90{ }^{\circ} \mathrm{C}$ under nitrogen atmosphere and reflux was kept for 5 h. Then, the mixture was cooled until room temperature, extracted with hexane/acetate $(7: 3)(315 \mathrm{~mL})$ and filtrated over Celite 535. The combined organic layers were washed with distilled water $(315 \mathrm{~mL})$, and dried over $\mathrm{Na}_{2} \mathrm{SO}_{4}$. Then, the organic solvent was evaporated under reduced pressure, to afford a brown solid in $90 \%$ yield without further purification steps.

${ }^{1} \mathrm{H} \mathrm{NMR}\left(300 \mathrm{MHz}, \mathrm{CDCl}_{3}\right): \delta(\mathrm{ppm}) 0.86(\mathrm{t}, J=6.65$ $\mathrm{Hz}, 3 \mathrm{H}), 1.30$ (m, 2H), 1.34 (quint, $J=6.64 \mathrm{~Hz}, 2 \mathrm{H}), 1.65$ (m, 2H), 1.67 (quint, $J=6.72 \mathrm{~Hz}, 2 \mathrm{H}$ ), 2.49 (t, $J=7.53 \mathrm{~Hz}$, $2 \mathrm{H}), 3.86(\mathrm{~s}, 3 \mathrm{H}), 3.87(\mathrm{~s}, 3 \mathrm{H}), 6.52(\mathrm{~s}, 1 \mathrm{H}), 6.79(\mathrm{~d}, J=$ $2.34 \mathrm{~Hz}, 1 \mathrm{H}), 7.22(\mathrm{~d}, J=2.34 \mathrm{~Hz}, 1 \mathrm{H}) .{ }^{13} \mathrm{C}$ NMR $(75 \mathrm{MHz}$,
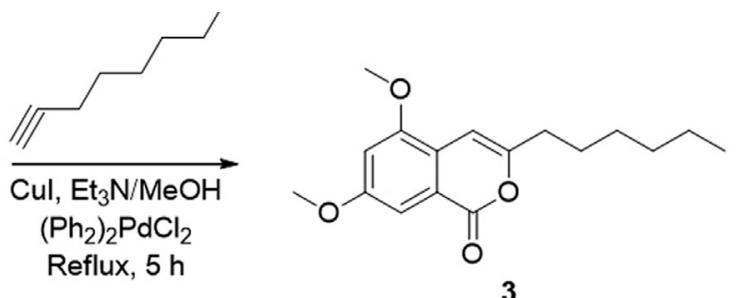

Figure 1 - Synthesis of new isocoumarin (3) from precursor compounds 1 and 2. 
$\left.\mathrm{CDCl}_{3}\right): \delta(\mathrm{ppm}) 14.04\left(\mathrm{CH}_{3}\right), 22.50\left(\mathrm{CH}_{2}\right), 27.02\left(\mathrm{CH}_{2}\right)$, $28.67\left(\mathrm{CH}_{2}\right), 33.52\left(\mathrm{CH}_{2}\right), 55.79\left(\mathrm{CH}_{3}\right), 55.87\left(\mathrm{CH}_{3}\right), 97.07$ $(\mathrm{CH}), 100.68(\mathrm{CH}), 105.09(\mathrm{CH}), 121.39(\mathrm{C}), 122.83(\mathrm{C})$, 155.00 (C), 155.68 (C), 159.58 (C), $163.32(\mathrm{C}=\mathrm{O})$. DEPT-135 ( $\uparrow$ ) $\mathrm{CH}$ and $\mathrm{CH}_{3}: 14.04,55.79,97.07,100.65$, 105.09; ( $\downarrow) \mathrm{CH}_{2}: 22.50,27.02,28.67,31.51,33.52$. GC-MS $\mathrm{m} / z$ (rel intensity) (EI, $70 \mathrm{eV}):\left[\mathrm{M}^{+}\right] 290(71.0 \%), 281$ (28.8\%), 253 (8.8\%), 220 (22.2\%), 219 (100.0\%), 191 (37.7\%), 178 (11.1\%), 161 (13.1\%), 149 (20.0\%), 133 (17.7\%), 84 (13.3\%), 73 (22.2\%), 57 (15.5\%), 49 (17.7\%).

\section{Chemical agents, animals and experimental design}

Two positive controls were used in the present study: cyclophosphamide and cisplatin. Cyclophosphamide (Fosfaseron $^{\circledR}$, Ithaca Laboratories, REG MS No. 1.2603.0056.002-1; Batch 063 020, Brazil) acts by alkylating cellular constituents through an indirect action that leads to the crosslinking of the DNA and to the disruption of transcription and translation. Cisplatin (Laboratory Intas Pharmaceuticals LTD, REG MS1.5537.0002.003-7; Matoda 382210, India) is an antineoplastic and antitumor agent that binds to DNA, resulting in intercalating links that induce structural changes and promote DNA transcription and replication inhibition. The chemotherapeutic agent cyclophosphamide was prepared in saline solution $(\mathrm{pH} 7.4)$ and administered at a concentration of $100 \mathrm{mg} / \mathrm{kg}$ (Oliveira et al., 2009a), and cisplatin was administered at $6 \mathrm{mg} / \mathrm{kg}$ body weight (bw) (Oliveira et al., 2009b). Both agents were administered intraperitoneally (ip) in a single dose. The new isocoumarin was first diluted in dimethylsulfoxide (DMSO) ( $1 \%$ final concentration) and then in Milli-Q water and administered at doses of 5,10 , and $20 \mathrm{mg} / \mathrm{kg}$ (bw, ip) (Chen et al., 2007).

One hundred and twenty sexually mature Swiss strain (Mus musculus) male mice were obtained from the Central Animal Laboratory of Biological Sciences Center and Health, Federal University of Mato Grosso do Sul (CCBS/UFMS) and divided into 12 experimental groups ( $\mathrm{n}$ $=10$ animals per group). The animals were housed in polypropylene cages covered with wood shavings and maintained with a commercial diet $\left(\mathrm{Nuvital}^{\circledR}\right)$ and filtered water ad libitum. A $12 \mathrm{~h}$ photoperiod (12 h light, $12 \mathrm{~h}$ dark) was used, and the temperature and humidity were set at $22 \pm 2{ }^{\circ} \mathrm{C}$ and $55 \pm 10 \%$, respectively, in a ventilated rack (ALESCO ${ }^{\circledR}$, Brazil). The experiment was conducted as described in the rules of the Brazilian College of Animal Experimentation and according to the guidelines of the Universal Declaration of Animal Rights, with the approval of the Ethics Committee on Animal Experiments of UFMS under protocol 399/2012.

The 12 experimental groups were divided as follows:

Negative control group: The animals received the vehicle of isocoumarin ( $1 \%$ DMSO) and of cyclophosphamide (saline $-0.9 \% \mathrm{NaCl}$ solution) at a dose of 0.1 $\mathrm{mL} / 10 \mathrm{~g}$ bw, ip simultaneously.
Cyclophosphamide group: The animals received isocoumarin vehicle $(0.1 \mathrm{~mL} / 10 \mathrm{~g} \mathrm{bw})$ and cyclophosphamide $(100 \mathrm{mg} / \mathrm{kg}$ bw, ip) simultaneously.

Cisplatin group: The animals received isocoumarin vehicle $(0.1 \mathrm{~mL} / 10 \mathrm{~g} \mathrm{bw})$ and cisplatin $(6 \mathrm{mg} / \mathrm{kg}$ bw, ip) simultaneously.

Isocoumarin group: The animals received isocoumarin at three different doses, i.e., $5 \mathrm{mg} / \mathrm{kg}, 10 \mathrm{mg} / \mathrm{kg}$ and $20 \mathrm{mg} / \mathrm{kg}$ bw, ip and cyclophosphamide vehicle $(0.1 \mathrm{~mL} / 10$ $\mathrm{g}$ bw, ip), simultaneously.

Combination Group I (isocoumarin + cyclophosphamide): The animals received the isocoumarin in three different doses, i.e., $5 \mathrm{mg} / \mathrm{kg}, 10 \mathrm{mg} / \mathrm{kg}$ and $20 \mathrm{mg} / \mathrm{kg}$ bw, ip, and cyclophosphamide (100 mg/kg bw, ip), simultaneously.

Combination Group II (isocoumarin + cisplatin): The animals received the isocoumarin in three different doses, i.e., $5 \mathrm{mg} / \mathrm{kg}, 10 \mathrm{mg} / \mathrm{kg}$ and $20 \mathrm{mg} / \mathrm{kg}$ bw, ip, and cisplatin (6 mg/kg bw, ip), simultaneously.

Peripheral blood samples $(20 \mu \mathrm{L})$ were collected for the comet and micronucleus test at 24 hours (T1) and for the micronucleus test at 48 (T2), and 72 hours (T3) after administration of the compounds. At T3, $20 \mu \mathrm{L}$ peripheral blood was also collected for differential blood cell analysis. Seventy-two hours after application of the test compounds, the animals were sacrificed by cervical dislocation for organ collection.

\section{Biological assays}

\section{Peripheral blood micronucleus assay}

The peripheral blood micronucleus assay was performed according to Hayashi et al. (1990) with modifications by Oliveira et al. (2009a). A drop of peripheral blood was deposited on a slide previously coated with $20 \mu \mathrm{L}$ of acridine orange $(1.0 \mathrm{mg} / \mathrm{mL})$, and the slide was covered with a coverslip. The slide remained in a freezer $\left(-20{ }^{\circ} \mathrm{C}\right)$ for two weeks. Analysis was performed using a fluorescence microscope (Bioval ${ }^{\circledR}$, L Model 2000A) under 400x magnification with a $420-490 \mathrm{~nm}$ excitation filter and a $520 \mathrm{~nm}$ barrier filter.

\section{Cell death assay}

For the cell death assay, $100 \mu \mathrm{L}$ of a solution of macerated liver or kidney was smeared onto a slide. Then, the slide was fixed in Carnoy solution for $10 \mathrm{~min}$. The slide was subjected to decreasing concentrations of ethanol (95\%-25\%) and was then soaked in McIlvaine buffer for $10 \mathrm{~min}$, followed by staining with acridine orange $(0.01 \%$, $5 \mathrm{~min}$ ) and a final wash with McIlvaine buffer for $10 \mathrm{~min}$. The identification of dead cells was performed by analyzing DNA fragmentation patterns according to Rovozzo and Burke (1973) and Mauro et al. (2011). 


\section{Splenic phagocytosis assay}

The splenic phagocytosis assay was performed by homogenizing the spleen in physiological solution, resulting in a cell suspension. A $100 \mu \mathrm{L}$ aliquot of the cell suspension was placed on a slide and covered with a coverslip. Before applying the cell suspension, $20 \mu \mathrm{L}$ of acridine orange (1.0 $\mathrm{mg} / \mathrm{mL}$ ) had been added to cover the entire surface of each preheated slide. The analysis was performed using a fluorescence microscope (Bioval ${ }^{\circledR}$, Model 2000A L) at a magnification of 400 with a $420-490 \mathrm{~nm}$ filter and a $520 \mathrm{~nm}$ barrier filter (Ishii et al., 2011). In total, 100 cells per animal or 1000 cells per group were analyzed. The analysis of cells for the presence or absence of phagocytosis was based on the description of Hayashi et al. (1990).

\section{Differential blood cell count}

To perform the differential blood cell count, $20 \mu \mathrm{L}$ of peripheral blood was smeared onto each histological slide. These were dried in open air and stained with Giemsa $(10 \%)$ for $10 \mathrm{~min}$. The slides were analyzed under bright field microscopy at 1000 magnification. In total, 100 cells/animal were analyzed and classified as lymphocytes, neutrophils, monocytes, eosinophils or basophils (Ishii et al., 2011).

\section{Calculation of percent damage reduction (DR\%)}

The calculation of the DR\% was performed to evaluate the chemopreventive properties of the novel compound when combined with a genotoxic substance according to Manoharan and Banerjee (1985) and to Waters et al. (1990). The DR\% was calculated as follows: [the mean of the positive control - the mean of the combination treatment] / (the mean of the positive control - the mean of the negative control). The result was multiplied by 100 to obtain the DR\%.

\section{Statistical analysis}

Data were analyzed by ANOVA with Tukey's posthoc test using GraphPad Prism software (version 2.3; Graph-Pad Software Inc., San Diego, CA, USA). The values are reported as the mean $\pm \mathrm{SE}$. The significance level was set at $\mathrm{p}<0.05$.

\section{Results}

\section{Synthesis}

As shown in Figure 1, the synthesis of isocoumarin (compound 3) was performed in good yields starting from commercially available 3,5-dimethoxybenzoic acid (compound 1). In the first step, the electrophilic aromatic iodination of compound 1 was performed using NIS in acetonitrile in the presence of a catalytic amount of trifluoroacetic acid. The corresponding iodinated compound 2 was obtained in $79 \%$ yield. Following, a crosscoupling Sonogashira reaction was carried out between the halogenated compound 2 and 1-octyne in a $\mathrm{NEt}_{3} / \mathrm{MeOH}$ solvent system to obtain the respective 2-alkynyl benzoic acid formed in situ which was treated with $\mathrm{NEt}_{3} / \mathrm{MeOH}$ to form the respective ammonium salt. This salt underwent CuI-catalyzed cyclization to give isocoumarin (3) in $90 \%$ yield.

The reason for this regioselectivity to form the isocoumarin (3) associated with a catalytic system using $\mathrm{CuI}$ and $\left(\mathrm{Ph}_{3} \mathrm{P}\right)_{2} \mathrm{PdCl}_{2}$ is not yet fully elucidated in the literature. According to Subramanian et al. (2005), the direction of this cyclization can be influenced by the nature of the catalyst systems, as well as by the solvent used in these reactions.

\section{Biological assays}

\section{Biometric parameters}

The biometric parameter analysis showed no difference between the mean values of initial and final body weights of the analyzed mice (Table 1). The absolute organ weights are presented in Table 2. Significant increases in lung and spleen weights were observed in the groups treated with single doses of isocoumarin $(5,10$ and 20 $\mathrm{mg} / \mathrm{kg}$ ). Increases in lung and spleen weights were also observed in the groups treated with isocoumarin combined with either chemotherapeutic agent $(\mathrm{p}<0.05)$, although these increases were more prominent in the group that received isocoumarin alone.

\section{Peripheral blood micronucleus assay}

A significant increase in the frequency of micronuclei was observed in the groups treated with the three doses of

Table 1 - Means \pm SE of the initial and final weights of Swiss mice treated with different doses of isocoumarin.

\begin{tabular}{lcc}
\hline Experimental groups & Initial weight $(\mathrm{g})$ & Final weight $(\mathrm{g})$ \\
\hline Negative control & $35.8 \pm 0.66^{\text {a }}$ & $35.0 \pm 0.75^{\text {a }}$ \\
Isocoum $5 \mathrm{mg} / \mathrm{kg}$ & $34.5 \pm 0.82^{\text {a }}$ & $33.9 \pm 0.70^{\text {a }}$ \\
Isocoum $10 \mathrm{mg} / \mathrm{kg}$ & $35.6 \pm 0.54^{\text {a }}$ & $34.8 \pm 0.66^{\text {a }}$ \\
Isocoum $20 \mathrm{mg} / \mathrm{kg}$ & $34.0 \pm 0.54^{\text {a }}$ & $33.0 \pm 0.52^{\text {a }}$ \\
Cyclophosphamide (CP) & $35.2 \pm 1.02^{\text {a }}$ & $33.0 \pm 1.05^{\text {a }}$ \\
CP + Isocoum $5 \mathrm{mg} / \mathrm{kg}$ & $35.8 \pm 0.82^{\text {a }}$ & $34.7 \pm 0.60^{\text {a }}$ \\
CP + Isocoum $10 \mathrm{mg} / \mathrm{kg}$ & $35.7 \pm 0.63^{\text {a }}$ & $34.6 \pm 0.73^{\text {a }}$ \\
CP + Isocoum $20 \mathrm{mg} / \mathrm{kg}$ & $34.1 \pm 0.47^{\text {a }}$ & $32.7 \pm 0.66^{\text {a }}$ \\
Cisplatin (CDDP) & $35.5 \pm 0.96^{\text {a }}$ & $34.2 \pm 0.64^{\text {a }}$ \\
CDDP + Isocoum $5 \mathrm{mg} / \mathrm{kg}$ & $34.3 \pm 0.60^{\text {a }}$ & $33.7 \pm 0.40^{\text {a }}$ \\
CDDP + Isocoum 10mg/kg & $34.1 \pm 0.68^{\text {a }}$ & $32.1 \pm 0.78^{\text {a }}$ \\
CDDP + Isocoum $20 \mathrm{mg} / \mathrm{kg}$ & $34.7 \pm 0.67^{\text {a }}$ & $33.7 \pm 0.89^{\text {a }}$ \\
\hline
\end{tabular}

SE - Standard error. Negative control - DMSO 1\%; Cyclophosphamide $100 \mathrm{mg} / \mathrm{kg}$ bw., ip.; Cisplatin $-6 \mathrm{mg} / \mathrm{kg}$, bw., ip. Isocoum. - Isocoumarin at doses $5,10,20 \mathrm{mg} / \mathrm{kg}$ bw, ip. CP + Isocoum. - Cyclophosphamide -100 $\mathrm{mg} / \mathrm{kg}$ (p.c.; i.p.) + Isocoumarin at doses 5, 10, $20 \mathrm{mg} / \mathrm{kg}$ bw., ip.; CDDP + Isocoum. - Cisplatin $-6 \mathrm{mg} / \mathrm{kg}$ bw., ip., + Isocoumarin at doses 5, 10, 20 $\mathrm{mg} / \mathrm{kg}$ bw., ip.; Different letters indicate statistically significant differences $(\mathrm{p}<0.05)$; ANOVA with Tukey post-hoc test. 
isocoumarins (5, 10 and $20 \mathrm{mg} / \mathrm{kg}$ ) at 24 (T1), 48 (T2) and 72 hours (T3) (Table 3). These results indicate that isocoumarin exhibits genotoxic activity. A decrease in micronucleus frequency was observed in the groups treated with isocoumarin in combination with either cyclophosphamide or cisplatin. These results suggest a decrease in the genotoxic effects of both chemotherapeutic agents in combination with isocoumarin.

Table 2 - Means \pm SE of the absolute weights of the animals' organs after the experimentation period.

\begin{tabular}{|c|c|c|c|c|c|}
\hline Experimental groups & Heart & Lungs & Liver & Kidneys & Spleen \\
\hline \multicolumn{6}{|c|}{ Absolute weight (g) } \\
\hline Negative control & $0.202 \pm 0.006^{\mathrm{a}}$ & $0.1750 .005^{\mathrm{a}}$ & $1.650 \pm 0.053^{\mathrm{a}}$ & $0.490 \pm 0.015^{\mathrm{a}}$ & $0.1580 .007^{\mathrm{a}}$ \\
\hline Isocoum $5 \mathrm{mg} / \mathrm{kg}$ & $0.230 \pm 0.009^{\mathrm{a}}$ & $0.311 \pm 0.010^{c}$ & $1.781 \pm 0.035^{\mathrm{a}}$ & $0.508 \pm 0.022^{\mathrm{a}}$ & $0.230 \pm 0.010^{b}$ \\
\hline Isocoum $10 \mathrm{mg} / \mathrm{kg}$ & $0.232 \pm 0.008^{\mathrm{a}}$ & $0.316 \pm 0.013^{c}$ & $1.798 \pm 0.029^{\mathrm{a}}$ & $0.500 \pm 0.023^{\mathrm{a}}$ & $0.233 \pm 0.010^{b}$ \\
\hline Isocoum $20 \mathrm{mg} / \mathrm{kg}$ & $0.231 \pm 0.007^{\mathrm{a}}$ & $0.315 \pm 0.009^{\mathrm{c}}$ & $1.780 \pm 0.025^{\mathrm{a}}$ & $0.507 \pm 0.013^{\mathrm{a}}$ & $0.231 \pm 0.012^{b}$ \\
\hline Cyclophosphamide (CP) & $0.231 \pm 0.006^{\mathrm{a}}$ & $0.2240 .006^{b}$ & $1.663 \pm 0.039^{\mathrm{a}}$ & $0.5250 .014^{\mathrm{a}}$ & $0.191 \pm 0.006^{\mathrm{ab}}$ \\
\hline $\mathrm{CP}+$ Isocoum $5 \mathrm{mg} / \mathrm{kg}$ & $0.234 \pm 0.006^{\mathrm{a}}$ & $0.260 \pm 0.007^{\mathrm{b}}$ & $1.681 \pm 0.028^{\mathrm{a}}$ & $0.491 \pm 0.014^{\mathrm{a}}$ & $0.1950 .016^{\mathrm{ab}}$ \\
\hline $\mathrm{CP}+$ Isocoum $10 \mathrm{mg} / \mathrm{kg}$ & $0.235 \pm 0.011^{\mathrm{a}}$ & $0.230 \pm 0.009^{\mathrm{b}}$ & $1.650 \pm 0.059^{\mathrm{a}}$ & $0.490 \pm 0.023^{\mathrm{a}}$ & $0.199 \pm 0.009^{\mathrm{ab}}$ \\
\hline $\mathrm{CP}+$ Isocoum $20 \mathrm{mg} / \mathrm{kg}$ & $0.230 \pm 0.013^{\mathrm{a}}$ & $0.230 \pm 0.008^{b}$ & $1.696 \pm 0.053^{\mathrm{a}}$ & $0.494 \pm 0.008^{\mathrm{a}}$ & $0.197 \pm 0.005^{\mathrm{ab}}$ \\
\hline Cisplatin (CDDP) & $0.234 \pm 0.013^{\mathrm{a}}$ & $0.2280 .015^{b}$ & $1.665 \pm 0.030^{\mathrm{a}}$ & $0.523 \pm 0.016^{\mathrm{a}}$ & $0.193 \pm 0.005^{\mathrm{ab}}$ \\
\hline $\mathrm{CDDP}+$ Isocoum $5 \mathrm{mg} / \mathrm{kg}$ & $0.213 \pm 0.008^{a}$ & $0.217 \pm 0.007^{\mathrm{ab}}$ & $1.693 \pm 0.073^{\mathrm{a}}$ & $0.500 \pm 0.017^{\mathrm{a}}$ & $0.198 \pm 0.008^{a b}$ \\
\hline $\mathrm{CDDP}+$ Isocoum $10 \mathrm{mg} / \mathrm{kg}$ & $0.211 \pm 0.010^{\mathrm{a}}$ & $0.2180 .006^{\mathrm{ab}}$ & $1.699 \pm 0.041^{\mathrm{a}}$ & $0.486 \pm 0.013^{\mathrm{a}}$ & $0.197 \pm 0.009^{\mathrm{ab}}$ \\
\hline $\mathrm{CDDP}+$ Isocoum $20 \mathrm{mg} / \mathrm{kg}$ & $0.214 \pm 0.009^{\mathrm{a}}$ & $0.213 \pm 0.033^{\mathrm{ab}}$ & $1.703 \pm 0.035^{\mathrm{a}}$ & $0.488 \pm 0.016^{\mathrm{a}}$ & $0.198 \pm 0.004^{\mathrm{ab}}$ \\
\hline
\end{tabular}

SE - Standard error. Negative control - DMSO 1\%; Cyclophosphamide - $100 \mathrm{mg} / \mathrm{kg}$ bw., ip.; Cisplatin - $6 \mathrm{mg} / \mathrm{kg}$, bw., ip. Isocoum. - Isocoumarin at doses 5, 10, $20 \mathrm{mg} / \mathrm{kg}$ bw, ip. CP + Isocoum. - Cyclophosphamide - $100 \mathrm{mg} / \mathrm{kg}$ (p.c.; i.p.) + Isocoumarin at doses 5, 10, $20 \mathrm{mg} / \mathrm{kg}$ bw., ip.; CDDP + Isocoum. - Cisplatin $-6 \mathrm{mg} / \mathrm{kg}$ bw., ip., + Isocoumarin at doses $5,10,20 \mathrm{mg} / \mathrm{kg}$ bw., ip.; Different letters indicate statistically significant differences $(\mathrm{p}<$ 0.05); ANOVA with Tukey post-hoc test.

Table 3 - Mean frequencies \pm SE of the damage reduction percentage as determined by the micronucleus assay in mouse peripheral blood cells.

\begin{tabular}{|c|c|c|c|c|c|c|}
\hline \multirow[t]{2}{*}{ Experimental groups } & \multicolumn{3}{|c|}{ Mean \pm SE } & \multicolumn{3}{|c|}{$\mathrm{DR} \%$} \\
\hline & $24 \mathrm{~h}(\mathrm{~T} 1)$ & $48 \mathrm{~h}(\mathrm{~T} 2)$ & $72 \mathrm{~h}(\mathrm{~T} 3)$ & $24 \mathrm{~h}(\mathrm{~T} 1)$ & $48 \mathrm{~h}(\mathrm{~T} 2)$ & $72 \mathrm{~h}(\mathrm{~T} 3)$ \\
\hline Negative control & $9.4 \pm 0.60^{\mathrm{a}}$ & $8.4 \pm 0.67^{\mathrm{a}}$ & $8.0 \pm 0.51^{\mathrm{a}}$ & - & - & - \\
\hline Cyclophosphamide (CP) & $110.4 \pm 1.27^{\mathrm{g}}$ & $97.3 \pm 0.37^{\mathrm{e}}$ & $91.51 .08^{\mathrm{d}}$ & - & - & - \\
\hline Isocoum $5 \mathrm{mg} / \mathrm{kg}$ & $23.4 \pm 0.96^{\mathrm{c}}$ & $16.3 \pm 0.84^{\mathrm{b}}$ & $23.7 \pm 1.06^{\mathrm{b}}$ & - & - & - \\
\hline Isocoum $10 \mathrm{mg} / \mathrm{kg}$ & $33.4 \pm 1.22^{\mathrm{d}}$ & $22.6 \pm 0.76^{\mathrm{c}}$ & $27.8 \pm 0.90^{\mathrm{b}}$ & - & - & - \\
\hline Isocoum $20 \mathrm{mg} / \mathrm{kg}$ & $66.1 \pm 1.51^{\mathrm{f}}$ & $29.1 \pm 0.67^{\mathrm{d}}$ & $37.1 \pm 1.31^{\mathrm{c}}$ & - & - & - \\
\hline $\mathrm{CP}+$ Isocoum $5 \mathrm{mg} / \mathrm{kg}$ & $16.5 \pm 0.72^{\mathrm{b}}$ & $23.5 \pm 0.80^{\mathrm{c}}$ & $37.4 \pm 1.19^{\mathrm{c}}$ & 93.0 & 83.0 & 64.8 \\
\hline $\mathrm{CP}+$ Isocoum $10 \mathrm{mg} / \mathrm{kg}$ & $33.2 \pm 1.14^{\mathrm{d}}$ & $23.7 \pm 0.79^{\mathrm{c}}$ & $28.4 \pm 0.98^{\mathrm{b}}$ & 76.4 & 82.8 & 75.6 \\
\hline $\mathrm{CP}+$ Isocoum $20 \mathrm{mg} / \mathrm{kg}$ & $55.81 .25^{\mathrm{e}}$ & $25.5 \pm 0.78^{\mathrm{c}}$ & $33.7 \pm 1.36^{\mathrm{c}}$ & 54.0 & 80.7 & 69.2 \\
\hline Negative control & $9.4 \pm 0.60^{\mathrm{a}}$ & $8.4 \pm 0.67^{\mathrm{a}}$ & $7.8 \pm 0.49^{\mathrm{a}}$ & - & - & - \\
\hline Cisplatin (CDDP) & $93.6 \pm 1.90^{\mathrm{g}}$ & $89.8 \pm 1.12^{\mathrm{g}}$ & $87.9 \pm 1.46^{\mathrm{e}}$ & - & - & - \\
\hline Isocoum $5 \mathrm{mg} / \mathrm{kg}$ & $23.4 \pm 0.96^{\mathrm{b}}$ & $16.3 \pm 0.84^{\mathrm{b}}$ & $23.7 \pm 1.06^{\mathrm{b}}$ & - & - & - \\
\hline Isocoum $10 \mathrm{mg} / \mathrm{kg}$ & $33.4 \pm 1.22^{\mathrm{c}}$ & $22.6 \pm 0.76^{\mathrm{c}}$ & $27.8 \pm 0.90^{\mathrm{b}}$ & - & - & - \\
\hline Isocoum $20 \mathrm{mg} / \mathrm{kg}$ & $66.1 \pm 1.51^{\mathrm{f}}$ & $29.1 \pm 0.67^{\mathrm{d}}$ & $37.1 \pm 1.31^{\mathrm{c}}$ & - & - & - \\
\hline $\mathrm{CDDP}+$ Isocoum $5 \mathrm{mg} / \mathrm{kg}$ & $49.7 \pm 1.44^{\mathrm{e}}$ & $57.5 \pm 0.97^{\mathrm{f}}$ & $38.2 \pm 1.29^{\mathrm{c}}$ & 52.1 & 39.7 & 62.0 \\
\hline $\mathrm{CDDP}+$ Isocoum $10 \mathrm{mg} / \mathrm{kg}$ & $41.0 \pm 1.23^{\mathrm{d}}$ & $30.4 \pm 1.54^{\mathrm{d}}$ & $48.0 \pm 1.37^{\mathrm{d}}$ & 62.5 & 73.0 & 49.8 \\
\hline CDDP + Isocoum $20 \mathrm{mg} / \mathrm{kg}$ & $49.5 \pm 1.46^{\mathrm{e}}$ & $38.5 \pm 0.99^{\mathrm{e}}$ & $52.5 \pm 1.26^{\mathrm{d}}$ & 52.4 & 63.0 & 44.2 \\
\hline
\end{tabular}

SE - Standard error. Negative control - DMSO 1\%; Cyclophosphamide - $100 \mathrm{mg} / \mathrm{kg}$ bw., ip.; Cisplatin - $6 \mathrm{mg} / \mathrm{kg}$, bw., ip. Isocoum. - Isocoumarin at doses 5, 10, $20 \mathrm{mg} / \mathrm{kg}$ bw, ip. CP + Isocoum. - Cyclophosphamide $-100 \mathrm{mg} / \mathrm{kg}$ (p.c.; i.p.) + Isocoumarin at doses 5, 10, $20 \mathrm{mg} / \mathrm{kg}$ bw., ip.; CDDP + Isocoum. - Cisplatin $-6 \mathrm{mg} / \mathrm{kg}$ bw., ip., + Isocoumarin at doses 5, 10, $20 \mathrm{mg} / \mathrm{kg}$ bw., ip.; DR\% - percent damage reduction. Different letters indicate statistically significant differences $(\mathrm{p}<0.05)$; ANOVA with Tukey post-hoc test. 


\section{Cell death assay}

The administration of isocoumarin at 5, 10 and 20 $\mathrm{mg} / \mathrm{kg}$ caused increases $(\mathrm{p}<0.05)$ in the rate of dead cells in the liver of approximately 1.79-, 1.76- and 2.45-fold, respectively, compared to that of the negative control. An increase in the frequency of dead cells was also observed in kidney $(p<0.05)$ compared to that of the negative control group. Additionally, the rate of dead cells was augmented by the administration of either cyclophosphamide or cisplatin alone $(\mathrm{p}<0.05)$ compared to that of the negative control group. The administration of cyclophosphamide resulted in increases in the frequencies of dead cells of approximately 2.47 -fold in the liver and 1.66 -fold in the kidney compared to those of the negative control group. The administration of the chemotherapeutic drug cisplatin increased the dead cell rates by 2.09 - and 1.76-fold in the liver and kidneys, respectively, compared to those of the negative control group. Combination group II presented a significant increase in the frequency of dead cells in the liver compared to that of the cisplatin group. In the kidneys, the increases in the dead cell rates were approximately 1.05 -fold and 1.03-fold with 5 and $20 \mathrm{mg} / \mathrm{kg}$ doses, respectively, compared with those of the cisplatin group. Additionally, an increase in the frequency of dead cells was observed in the kidneys of combination group I compared to that of the cyclophosphamide group (Table 4).

\section{Splenic phagocytosis}

The administration of the new isocoumarin at doses of 5,10 and $20 \mathrm{mg} / \mathrm{kg}$ demonstrated its ability to alter splenic phagocytosis as evidenced by increases in the numbers of cells with phagocytosis $(\mathrm{p}<0.05)$ of approximately 1.69-, 1.71-, and 1.71-fold compared to those of the negative control group. The combination of isocoumarin dosages with cyclophosphamide or cisplatin also increased phagocytic events. An increase in the mean frequency of cells with evidence of splenic phagocytosis was observed in combination group I compared to that in the cyclophosphamide group. The same tendency was observed for combination group II, which also presented an increased frequency of cells with splenic phagocytosis compared to that of the cisplatin group (Table 5).

\section{Differential blood cell count}

The differential counting of blood cells showed that the administration of the new isocoumarin at doses of 5,10 and $20 \mathrm{mg} / \mathrm{kg}$ increased lymphocyte numbers and reduced neutrophil number $(\mathrm{p}<0.05)$. The isocoumarin, cyclophosphamide and cisplatin groups presented higher mean

Table 4 - Absolute values (AV) and mean \pm SE of dead cells in kidneys and liver of Swiss mice.

\begin{tabular}{|c|c|c|c|c|c|c|c|}
\hline \multirow[t]{3}{*}{ Experimental groups } & \multirow[t]{3}{*}{ Total of cells } & \multicolumn{6}{|c|}{ Number of dead cells } \\
\hline & & \multicolumn{3}{|c|}{ Liver } & \multicolumn{3}{|c|}{ Kidneys } \\
\hline & & AV & Mean \pm SE & $(\%)$ & AV & Mean \pm SE & $(\%)$ \\
\hline Negative control & 1000 & 147 & $14.7 \pm 0.56^{\mathrm{a}}$ & 14.7 & 164 & $16.4 \pm 0.62^{\mathrm{a}}$ & 16.4 \\
\hline Cyclophosphamide (CP) & 1000 & 363 & $36.3 \pm 1.13^{\mathrm{d}}$ & 36.3 & 273 & $27.3 \pm 0.73^{b}$ & 27.3 \\
\hline Isocoum $5 \mathrm{mg} / \mathrm{kg}$ & 1000 & 264 & $26.4 \pm 1.16^{\mathrm{b}}$ & 26.4 & 274 & $27.4 \pm 0.65^{\mathrm{bc}}$ & 27.4 \\
\hline Isocoum $10 \mathrm{mg} / \mathrm{kg}$ & 1000 & 259 & $25.9 \pm 1.20^{\mathrm{b}}$ & 25.9 & 260 & $26.0 \pm 0.77^{\mathrm{b}}$ & 26.0 \\
\hline Isocoum $20 \mathrm{mg} / \mathrm{kg}$ & 1000 & 361 & $36.1 \pm 0.75^{\mathrm{d}}$ & 36.1 & 267 & $26.7 \pm 0.73^{b}$ & 26.7 \\
\hline $\mathrm{CP}+$ Isocoum $5 \mathrm{mg} / \mathrm{kg}$ & 1000 & 368 & $36.8 \pm 0.70^{\mathrm{d}}$ & 36.8 & 307 & $30.7 \pm 0.98^{\mathrm{cd}}$ & 30.7 \\
\hline $\mathrm{CP}+$ Isocoum $10 \mathrm{mg} / \mathrm{kg}$ & 1000 & 310 & $31.0 \pm 0.54^{\mathrm{c}}$ & 31.0 & 313 & $31.3 \pm 0.77^{\mathrm{d}}$ & 31.3 \\
\hline $\mathrm{CP}+$ Isocoum $20 \mathrm{mg} / \mathrm{kg}$ & 1000 & 360 & $36.0 \pm 0.54^{\mathrm{d}}$ & 36.0 & 310 & $31.0 \pm 0.68^{\mathrm{d}}$ & 31.0 \\
\hline Negative control & 1000 & 147 & $14.7 \pm 0.56^{\mathrm{a}}$ & 14.7 & 164 & $16.4 \pm 0.62^{\mathrm{a}}$ & 16.4 \\
\hline Cisplatin (CDDP) & 1000 & 307 & $30.7 \pm 1.50^{\mathrm{c}}$ & 30.7 & 289 & $28.9 \pm 0.81 \mathrm{bcd}$ & 28.9 \\
\hline Isocoum $5 \mathrm{mg} / \mathrm{kg}$ & 1000 & 264 & $26.4 \pm 1.16^{\mathrm{bc}}$ & 26.4 & 274 & $27.4 \pm 0.65^{\text {bcd }}$ & 27.4 \\
\hline Isocoum $10 \mathrm{mg} / \mathrm{kg}$ & 1000 & 259 & $25.9 \pm 1.20^{\mathrm{b}}$ & 25.9 & 260 & $26.0 \pm 0.77^{\mathrm{b}}$ & 26.0 \\
\hline Isocoum $20 \mathrm{mg} / \mathrm{kg}$ & 1000 & 361 & $36.1 \pm 0.75^{\mathrm{d}}$ & 36.1 & 267 & $26.7 \pm 0.73^{\mathrm{bc}}$ & 26.7 \\
\hline CDDP + Isocoum $5 \mathrm{mg} / \mathrm{kg}$ & 1000 & 340 & $34.0 \pm 1.01^{\mathrm{cd}}$ & 34.0 & 304 & $30.4 \pm 0.76^{\mathrm{d}}$ & 30.4 \\
\hline CDDP + Isocoum $10 \mathrm{mg} / \mathrm{kg}$ & 1000 & 334 & $33.4 \pm 1.13^{\mathrm{cd}}$ & 33.4 & 286 & $28.6 \pm 0.62 \mathrm{bcd}$ & 28.6 \\
\hline CDDP + Isocoum $20 \mathrm{mg} / \mathrm{kg}$ & 1000 & 350 & $35.0 \pm 1.02^{\mathrm{cd}}$ & 35.0 & 298 & $29.8 \pm 0.77^{\mathrm{cd}}$ & 29.8 \\
\hline
\end{tabular}

$\mathrm{SE}$ - Standard error. Negative control - DMSO 1\%; Cyclophosphamide - $100 \mathrm{mg} / \mathrm{kg}$ bw., ip.; Cisplatin - $6 \mathrm{mg} / \mathrm{kg}$, bw., ip. Isocoum. - Isocoumarin at doses 5, 10, $20 \mathrm{mg} / \mathrm{kg} \mathrm{bw}$, ip. CP + Isocoum. - Cyclophosphamide - $100 \mathrm{mg} / \mathrm{kg}$ (p.c.; i.p.) + Isocoumarin at doses 5, 10, $20 \mathrm{mg} / \mathrm{kg}$ bw., ip.; CDDP + Isocoum. - Cisplatin $-6 \mathrm{mg} / \mathrm{kg}$ bw., ip., + Isocoumarin at doses 5, 10, $20 \mathrm{mg} / \mathrm{kg}$ bw., ip.; Different letters indicate statistically significant differences $(\mathrm{p}<$ 0.05); ANOVA with Tukey post-hoc test. 
Table 5 - Analyzed cell numbers, absolute values (AV), mean frequency \pm SE, and cell percentages with or without evidence of splenic phagocytosis in Swiss mice treated with different doses of isocoumarin.

\begin{tabular}{|c|c|c|c|c|c|c|c|}
\hline \multirow[t]{2}{*}{ Experimental groups } & \multirow[t]{2}{*}{ Total of cells } & \multicolumn{3}{|c|}{ Cells without phagocytosis evidence } & \multicolumn{3}{|c|}{ Cells with phagocytosis evidence } \\
\hline & & AV & Mean \pm SE & $(\%)$ & AV & Mean \pm SE & $(\%)$ \\
\hline Negative control & 1000 & 495 & $49.5 \pm 0.40^{\mathrm{d}}$ & 49.5 & 505 & $50.5 \pm 0.40^{\text {a }}$ & 50.5 \\
\hline Cyclophosphamide (CP) & 1000 & 344 & $34.4 \pm 0.79^{\mathrm{c}}$ & 34.4 & 656 & $65.6 \pm 0.79^{b}$ & 65.6 \\
\hline Isocoum $5 \mathrm{mg} / \mathrm{kg}$ & 1000 & 144 & $14.4 \pm 0.65^{\mathrm{a}}$ & 14.4 & 856 & $85.6 \pm 0.65^{\mathrm{d}}$ & 85.6 \\
\hline Isocoum $10 \mathrm{mg} / \mathrm{kg}$ & 1000 & 134 & $13.4 \pm 0.40^{\text {a }}$ & 14.0 & 866 & $86.6 \pm 0.40^{\mathrm{d}}$ & 86.6 \\
\hline Isocoum $20 \mathrm{mg} / \mathrm{kg}$ & 1000 & 138 & $13.8 \pm 0.83^{\mathrm{a}}$ & 13.8 & 862 & $86.2 \pm 0.83^{\mathrm{d}}$ & 86.2 \\
\hline $\mathrm{CP}+$ Isocoum $5 \mathrm{mg} / \mathrm{kg}$ & 1000 & 261 & $26.1 \pm 0.64^{\mathrm{b}}$ & 26.1 & 739 & $73.9 \pm 0.64^{\mathrm{c}}$ & 73.9 \\
\hline $\mathrm{CP}+$ Isocoum $10 \mathrm{mg} / \mathrm{kg}$ & 1000 & 250 & $25.0 \pm 0.39^{b}$ & 25.0 & 750 & $75.0 \pm 0.39^{\mathrm{c}}$ & 75.0 \\
\hline $\mathrm{CP}+$ Isocoum $20 \mathrm{mg} / \mathrm{kg}$ & 1000 & 260 & $26.0 \pm 0.76^{\mathrm{b}}$ & 26.0 & 740 & $74.0 \pm 0.76^{\mathrm{c}}$ & 74.0 \\
\hline Negative control & 1000 & 495 & $49.5 \pm 0.40^{\mathrm{d}}$ & 49.5 & 505 & $50.5 \pm 0.40^{\text {a }}$ & 50.5 \\
\hline Cisplatin (CDDP) & 1000 & 403 & $40.3 \pm 0.42^{\mathrm{c}}$ & 40.3 & 597 & $59.7 \pm 0.42^{b}$ & 59.7 \\
\hline Isocoum $5 \mathrm{mg} / \mathrm{kg}$ & 1000 & 144 & $14.4 \pm 0.66^{\mathrm{a}}$ & 14.4 & 856 & $85.2 \pm 0.66^{\mathrm{d}}$ & 85.2 \\
\hline Isocoum $10 \mathrm{mg} / \mathrm{kg}$ & 1000 & 134 & $13.4 \pm 0.40^{\text {a }}$ & 13.4 & 866 & $86.6 \pm 0.40^{\mathrm{d}}$ & 86.6 \\
\hline Isocoum $20 \mathrm{mg} / \mathrm{kg}$ & 1000 & 138 & $13.8 \pm 0.83^{\mathrm{a}}$ & 13.8 & 862 & $86.2 \pm 0.83^{\mathrm{d}}$ & 86.2 \\
\hline $\mathrm{CDDP}+$ Isocoum $5 \mathrm{mg} / \mathrm{kg}$ & 1000 & 361 & $36.1 \pm 0.64^{\mathrm{b}}$ & 36.2 & 639 & $63.9 \pm 0.64^{\mathrm{c}}$ & 63.9 \\
\hline $\mathrm{CDDP}+$ Isocoum $10 \mathrm{mg} / \mathrm{kg}$ & 1000 & 366 & $36.6 \pm 0.75^{b}$ & 36.6 & 634 & $63.4 \pm 0.75^{\mathrm{c}}$ & 63.4 \\
\hline $\mathrm{CDDP}+$ Isocoum $20 \mathrm{mg} / \mathrm{kg}$ & 1000 & 358 & $35.8 \pm 0.88^{b}$ & 35.8 & 642 & $64.2 \pm 0.88^{\mathrm{c}}$ & 64.2 \\
\hline
\end{tabular}

SE - Standard error. Negative control - DMSO 1\%; Cyclophosphamide - $100 \mathrm{mg} / \mathrm{kg}$ bw., ip.; Cisplatin - $6 \mathrm{mg} / \mathrm{kg}$, bw., ip. Isocoum. - Isocoumarin at doses 5, 10, $20 \mathrm{mg} / \mathrm{kg}$ bw, ip. CP + Isocoum. - Cyclophosphamide - $100 \mathrm{mg} / \mathrm{kg}$ (p.c.; i.p.) + Isocoumarin at doses 5, 10, $20 \mathrm{mg} / \mathrm{kg}$ bw., ip.; CDDP + Isocoum. - Cisplatin $-6 \mathrm{mg} / \mathrm{kg}$ bw., ip., + Isocoumarin at doses 5, 10, $20 \mathrm{mg} / \mathrm{kg}$ bw., ip.; Different letters indicate statistically significant differences $(\mathrm{p}<$ 0.05); ANOVA with Tukey post-hoc test.

numbers of monocytes compared to the reference values. Moreover, an increase in the mean number of monocytes was observed in the isocoumarin group compared to that in the negative control group (Table 6).

\section{Discussion}

The search for new, pharmacologically functional, phenolic compounds has led to the discovery and synthesis of many drugs with anticancer activity (Queiroz et al., 2009; Kaminskyy et al., 2014; Navarro et al., 2014). These compounds include synthetic isocoumarins (Yin et al., 2001), which present antioxidant, antitumor and antiinflammatory activity in vivo (Yin et al., 2001; Curini et al., 2004; Lacy and O’Kennedy, 2004).

Genotoxicity, immunomodulation and apoptosis assays are suitable for the toxicological assessment of new drug candidates (Lacy and O'Kennedy, 2004) and were used in this study (Comet/micronucleus - genotoxicity; alteration of spleen phagocytosis and leukometry suggesting immunomodulation; and the cell death assay). Also, these tests are considered fundamental pre-indicative models for evaluating the frequencies of DNA and chromosome damage that are able to induce cancer development (Lacy and O’Kennedy, 2004; Mauro et al., 2011).
The new isocoumarin demonstrated high genotoxic potential in a micronucleus test. The toxic effects of many coumarins have been studied by the Food and Drug Administration (FDA) and by the United States National Toxicology Program of the National Institute of Environmental Health Sciences due to the use of such compounds on a large scale in the production of fragrances and flavor enhancers (Yourick and Bronaugh, 1997). High doses of coumarin are toxic and have genotoxic potential in in vivo experiments with rats and mice (Lake, 1984, 1999; Yin et al., 2001); however, doses that are toxic in rats are not toxic for humans (Lacy and O'Kennedy, 2004; Napimogaa and Yatsuda, 2010). The new isocoumarin synthesized in this study is classified as a phenolic lipid because a hydrophobic chain was incorporated into the initial coumarin (compound 2). Phenolic lipids are known to have antigenotoxic potential (Parikka et al., 2006; Melo-Cavalcante et al., 2008; Stasiuk and Kozubek, 2010; Navarro et al., 2014). However, the new isocoumarin exhibited strong genotoxic activity, which is consistent with the known high genotoxic potential resulting from the chemical properties of coumarins (Lake, 1984, 1999; Yourick and Bronaugh, 1997; Born et al., 1999; Borges et al., 2009; Napimogaa and Yatsuda, 2010).

The new isocoumarin presents a hydrophobic chain, which is likely related to DNA protection, and a phenolic 
Table 6 - Reference values and mean \pm SE of the differential blood cell count in Swiss mice treated with different doses of isocoumarin.

\begin{tabular}{|c|c|c|c|c|c|}
\hline Cell type & Lymphocytes & Neutrophils & Monocytes & Eosinophils & Basophils \\
\hline Reference values & $55-95 \%$ & $10-40 \%$ & $0.1-3.5 \%$ & $0-0.4 \%$ & $0-0.3 \%$ \\
\hline \multicolumn{6}{|c|}{ Experimental groups } \\
\hline Negative control & $49.2 \pm 2.10^{\mathrm{a}}$ & $45.8 \pm 1.62^{\mathrm{e}}$ & $3.2 \pm 0.42^{\mathrm{abc}}$ & $1.8 \pm 0.633^{\mathrm{ab}}$ & $0.0 \pm 0.00^{\mathrm{a}}$ \\
\hline Cyclophosphamide (CP) & $54.2 \pm 0.79^{b}$ & $39.7 \pm 0.82^{d}$ & $5.2 \pm 0.42^{\mathrm{d}}$ & $0.9 \pm 057^{\mathrm{a}}$ & $0.0 \pm 0.00^{\mathrm{a}}$ \\
\hline Isocoum $5 \mathrm{mg} / \mathrm{kg}$ & $52.2 \pm 1.81^{\mathrm{ab}}$ & $33.71 .25^{\mathrm{c}}$ & $4.2 \pm 0.42^{\mathrm{cd}}$ & $9.9 \pm 0.99^{b}$ & $0.0 \pm 0.00^{\mathrm{a}}$ \\
\hline Isocoum $10 \mathrm{mg} / \mathrm{kg}$ & $62.3 \pm 2.00^{\mathrm{c}}$ & $28.0 \pm 1.33^{b}$ & $4.5 \pm 0.71^{\mathrm{cd}}$ & $5.2 \pm 0.63^{b}$ & $0.0 \pm 0.00^{\mathrm{a}}$ \\
\hline Isocoum $20 \mathrm{mg} / \mathrm{kg}$ & $67.8 \pm 1.47^{\mathrm{d}}$ & $27.0 \pm 2.11^{b}$ & $3.9 \pm 0.74^{\text {bcd }}$ & $1.3 \pm 1.16^{\mathrm{a}}$ & $0.0 \pm 0.00^{\mathrm{a}}$ \\
\hline $\mathrm{CP}+$ Isocoum $5 \mathrm{mg} / \mathrm{kg}$ & $76.5 \pm 6.96^{\mathrm{e}}$ & $21.4 \pm 6.52^{\mathrm{a}}$ & $1.4 \pm 0.51^{\mathrm{a}}$ & $0.7 \pm 0.48^{\mathrm{a}}$ & $0.0 \pm 0.00^{\mathrm{a}}$ \\
\hline $\mathrm{CP}+$ Isocoum $10 \mathrm{mg} / \mathrm{kg}$ & $68.5 \pm 1.08^{\mathrm{d}}$ & $28.2 \pm 1.13^{b}$ & $2.2 \pm 0.79^{\mathrm{ab}}$ & $1.1 \pm 0.31^{\mathrm{a}}$ & $0.0 \pm 0.00^{\mathrm{a}}$ \\
\hline $\mathrm{CP}+$ Isocoum $20 \mathrm{mg} / \mathrm{kg}$ & $79.3 \pm 1.83^{\mathrm{e}}$ & $17.9 \pm 1.85^{\mathrm{a}}$ & $1.8 \pm 0.63^{\mathrm{a}}$ & $1.0 \pm 0.00^{\mathrm{a}}$ & $0.0 \pm 0.00^{\mathrm{a}}$ \\
\hline Negative control & $49.2 \pm 2.10^{\mathrm{a}}$ & $45.8 \pm 1.62^{\mathrm{e}}$ & $3.2 \pm 0.42^{\mathrm{bcd}}$ & $1.8 \pm 0.63^{\mathrm{ab}}$ & $0.0 \pm 0.00^{\mathrm{a}}$ \\
\hline Cisplatin (CDDP) & $56.3 \pm 2.16^{\mathrm{c}}$ & $37.7 \pm 2.83^{\mathrm{d}}$ & $4.6 \pm 1.26^{\mathrm{d}}$ & $1.50 .71^{\mathrm{a}}$ & $0.0 \pm 0.00^{\mathrm{a}}$ \\
\hline Isocoum $5 \mathrm{mg} / \mathrm{kg}$ & $52.2 \pm 1.81^{\mathrm{b}}$ & $33.71 .25^{\mathrm{c}}$ & $4.2 \pm 0.42^{\mathrm{d}}$ & $9.9 \pm 0.99^{b}$ & $0.0 \pm 0.00^{\mathrm{a}}$ \\
\hline Isocoum $10 \mathrm{mg} / \mathrm{kg}$ & $62.3 \pm 2.00^{\mathrm{d}}$ & $28.0 \pm 1.33^{b}$ & $4.5 \pm 0.71^{\mathrm{d}}$ & $5.2 \pm 0.63^{b}$ & $0.0 \pm 0.00^{\mathrm{a}}$ \\
\hline Isocoum $20 \mathrm{mg} / \mathrm{kg}$ & $67.8 \pm 1.47^{\mathrm{e}}$ & $27.0 \pm 2.11^{\mathrm{b}}$ & $3.9 \pm 0.74^{\mathrm{cd}}$ & $1.3 \pm 1.16^{\mathrm{a}}$ & $0.0 \pm 0.00^{\mathrm{a}}$ \\
\hline $\mathrm{CDDP}+$ Isocoum $5 \mathrm{mg} / \mathrm{kg}$ & $81.0 \pm 0.81^{\mathrm{f}}$ & $16.8 \pm 0.92^{\text {a }}$ & $2.1 \pm 0.57^{\mathrm{abc}}$ & $0.1 \pm 0.31^{\mathrm{a}}$ & $0.0 \pm 0.00^{\mathrm{a}}$ \\
\hline $\mathrm{CDDP}+$ Isocoum $10 \mathrm{mg} / \mathrm{kg}$ & $66.2 \pm 2.04^{\mathrm{e}}$ & $33.2 \pm 1.87^{\mathrm{c}}$ & $0.1 \pm 0.31^{\mathrm{a}}$ & $0.5 \pm 0.53^{\mathrm{a}}$ & $0.0 \pm 0.00^{\mathrm{a}}$ \\
\hline $\mathrm{CDDP}+$ Isocoum $20 \mathrm{mg} / \mathrm{kg}$ & $80.7 \pm 1.50^{\mathrm{f}}$ & $18.61 .58^{\mathrm{a}}$ & $0.6 \pm 0.51^{\mathrm{ab}}$ & $0.1 \pm 0.31^{\mathrm{a}}$ & $0.0 \pm 0.00^{\mathrm{a}}$ \\
\hline
\end{tabular}

SE - Standard error. Negative control - DMSO 1\%; Cyclophosphamide - $100 \mathrm{mg} / \mathrm{kg}$ bw., ip.; Cisplatin $-6 \mathrm{mg} / \mathrm{kg}$, bw., ip. Isocoum. - Isocoumarin at doses 5, 10, $20 \mathrm{mg} / \mathrm{kg}$ bw, ip. CP + Isocoum. - Cyclophosphamide - 100mg/kg (p.c.; i.p.) + Isocoumarin at doses 5, 10, $20 \mathrm{mg} / \mathrm{kg}$ bw., ip.; CDDP + Isocoum. - Cisplatin $-6 \mathrm{mg} / \mathrm{kg}$ bw., ip., + Isocoumarin at doses 5, 10, $20 \mathrm{mg} / \mathrm{kg}$ bw., ip.; Different letters indicate statistically significant differences $(\mathrm{p}<$ $0.05)$; ANOVA with Tukey post-hoc test.

ring, which is likely related to DNA damage. Thus, these two chemical characteristics are incorporated in the same compound, and an antagonist activity is observed. When tested alone, the new isocoumarin has genotoxic potential, and when tested in combination with either chemotherapeutic agent (cisplatin or cyclophosphamide), antigenotoxic and chemopreventive activities were observed. Consequently, we hypothesize that this new compound has bifunctional activity.

Our results corroborate results obtained by other authors regarding antigenotoxic activity (Melo-Cavalcante $e t$ al., 2008; Stasiuk and Kozubek, 2010). The new isocoumarin presented a substantial $\mathrm{DR} \%$, which is indicative of great chemoprevention when combined with cyclophosphamide or cisplatin. Additionally, the results did not show a dose-response relationship or a correlation between the time of compound metabolism and DNA damage reduction.

The various classes of coumarin have been widely studied for their antioxidant activities (Nishiyama et al., 2001; Di Stasi et al., 2004; Fylaktakidou, et al., 2004; Luchini et al., 2008). Antioxidant characteristics are associated with anti-inflammatory/inflammatory (Fedel-Miyasato et al., 2014), immunomodulatory (Murakami et al., 2000; Ishii et al., 2011) and chemopreventive activity (Oli- veira et al., 2013, 2014). Superoxide anions are free radicals that can cause lesions in the DNA and in tissues, primarily because of the infiltration of neutrophils in the tissues and because of the action of the phagocytary neutrophils (Murakami et al., 2000). According to Murakami et al. (2000), 7,8-dihydroxy coumarins are capable of sequestering superoxide anions and thus of exerting antioxidative action. Considering these findings, this sequestering could be responsible for the chemopreventive potential (Oliveira et al., 2006) of this new isocoumarin.

The anti-cancer activity of coumarin was confirmed in a study that used a compound extracted from fresh leaves of Mikania glomerata (Napimogaa and Yatsuda, 2010). Other studies have described synthetic and natural coumarins as promising compounds for the treatment of cancer because of their toxic properties resulting from their benzene and 1,2-pyrone rings (Lake, 1984, 1999; Born et al., 1999; Yin et al., 2001; Lacy and O'Kennedy, 2004; Chen et al., 2007; Borges et al., 2009; Napimogaa and Yatsuda, 2010). The present research provided an initial analysis of this new isocoumarin, and great genotoxic activity was observed. Such potential could classify this new compound as a chemotherapeutic agent. The frequencies of damage observed for this new isocoumarin are 59.9 and $70.6 \%$ of the damage caused by cyclophosphamide and cisplatin, respec- 
tively. However, when the new isocoumarin was combined with either chemotherapeutic agents, antigenotoxic activity was observed, which could compromise the capacity of DNA damage induction, thus compromising apoptosis caused by chemotherapy. This fact eliminates the possibilities of the combined administration of the new isocoumarin with these chemotherapeutic agents. Additionally, our results are in disagreement with data observed in the study by Navarro et al. (2014) because these authors found that the resorcinolic lipid AMS35AA has the capacity to potentiate the chemotherapeutic effect of cyclophosphamide. We infer from these discrepancies that different phenolic lipids have different modes of action.

Regarding dead cells in the liver and in the kidneys, the new isocoumarin promoted the same frequencies as did cyclophosphamide and cisplatin. In addition, the strong genotoxic potential of the new isocoumarin suggests that further studies are needed to understand and verify its chemotherapy potential. The toxic, apoptotic, and genotoxic potential of coumarins has already been described by Yin et al. (2001); Agata et al. (2004); Chen et al. (2007).

Importantly, coumarins are capable of increasing apoptotic events in tissues through their benzene and 1,2pyrone rings. Although the mechanisms of coumarininduced apoptosis are not entirely clear, different studies show that coumarins may increase the frequency of apoptosis by modulating pro-apoptotic genes (Bhattacharyya et al., 2009; Zhang et al., 2012; Shokoohinia et al., 2014). Thus, the mechanism of cell death would not involve DNA damage. Therefore, the new isocoumarin herein tested could exert both chemopreventive potential and induce cell death by apoptosis.

When combining the new isocoumarin with either chemotherapeutic agent, the inhibition and induction of apoptosis were not observed. Because a chemopreventive potential was observed, as shown by the high $\mathrm{DR} \%$ in the combination groups, a reduction in apoptosis was expected, but it did not occur. Thus, further studies of this new compound are required. Vukicevic et al. (2004) and Oliveira et al. (2007) have already shown that the frequency of apoptotic cells can be maintained when facing genetic damage that did not develop into micronuclei. Thus, the frequency of apoptotic events caused by an alkylating agent can be maintained even in the presence of chemopreventive compounds.

When analyzing the results of the splenic phagocytosis assay, we observed that both cyclophosphamide and cisplatin promoted increases in the frequency of micronuclei and, thus, increases in splenic phagocytosis. Splenic phagocytosis is a mechanism used to remove injured cells from the body, including those with micronuclei (Ishii et al., 2011; Fedel-Miyasato et al., 2014). When the new isocoumarin was administered alone, an increase in splenic phagocytosis was observed. The ability to alter splenic activity and chemotherapy potential were observed for the isocoumarin highest tested dose. Additionally, the increases in apoptotic events in the kidneys and liver corroborate these findings because they are significant when compared to the capacities of both positive controls (cyclophosphamide and cisplatin) to induce apoptosis in these organs.

Phagocytic activity also increased when the new isocoumarin was administered in combination with either chemotherapy drug. However, this particular increase was lower than that observed with the new isocoumarin administered alone. When interpreting this result, three events must be considered: the activity of chemoprevention, the maintenance of apoptotic events and the increase in phagocytic events. Generally, antimutagenesis modes of action are described as desmutagenesis and bioantimutagenesis (Oliveira et al., 2007, 2009a, 2009b, 2013, 2014). Therefore, antimutagenesis also occurs by splenic activity (Ishii et al., 2011; Fedel-Miyasato et al., 2014; Navarro et al., 2014). Thus, the chemopreventive activity of the new isocoumarin could be related to the increase in splenic phagocytosis, in addition to desmutagenesis and bioantimutagenesis, which are classic modes of action described by by Kada et al. (1982) and Kada and Shimoi (1987) and are now considered also genotoxic damage. If cells with micronuclei (genotoxic lesions) are removed from the blood by splenic phagocytosis before apoptosis occurs, then maintaining the frequency of apoptosis in the liver and kidneys can be explained even in the presence of a chemopreventive effect. Taken together, these data suggest that apoptosis could be responsible for the removal of damaged cells from the body, preventing their identification and quantification in peripheral blood by the micronucleus assay (Vukicevic et al., 2004; Oliveira et al., 2007).

The differential blood cell count supports the immunomodulatory activity that was observed in the phagocytosis assay. The reduction of neutrophils is related to the increase in splenic phagocytosis because of the migration of neutrophils to tissues (e.g., the spleen) where they exert their phagocytic function (Luchini et al., 2008). Additionally, the new isocoumarin, alone or in combination with either chemotherapeutic agent, is capable of increasing the frequency of lymphocytes. Patients who undergo chemotherapy become immunosuppressed (Rasmussen and Arvin, 1982), and reduced frequencies of lymphocytes compromise new cycles of chemotherapy. This important adverse effect is undesirable in new chemotherapy drugs (Navarro et al., 2014).

The new isocoumarin exhibits more than one characteristic of chemotherapeutic agents. Although it promoted an increase in splenic activity and altered the leukometry in animals treated with cyclophosphamide and cisplatin, the cost $v s$. benefit analysis of this drug must be evaluated because the combination of these compounds reduced the frequency of genotoxic damage and maintained apoptotic events, thus reducing the chemotherapeutic effects of cis- 
platin and cyclophosphamide. Therefore, the capability of the new isocoumarin to increase splenic activity and alter leukometry when administered alone, as well as its genotoxic and apoptotic activities, and phagocytosis induction potential are important characteristics in the search for a new chemotherapy agent and must be considered in the development of new antitumor compounds.

Although the new isocoumarin is not likely to be an adjuvant to chemotherapy treatments that use cyclophosphamide or cisplatin, the compound merits to be considered as a prototype for the development of new antitumor drugs.

\section{Acknowledgments}

This study was supported by the Mato Grosso do Sul Foundation for the Development of Education, Science and Technology (Fundação de Apoio ao Desenvolvimento do Ensino, Ciência e Tecnologia do Estado de Mato Grosso do Sul, FUNDECT). FHSA and JRP received scholarships from CAPES.

\section{References}

Agata N, Nogi H, Milhollen M, Kharbanda S and Kufe D (2004) 2-(8-Hydroxy-6-methoxy-1-oxo-1H-2-benzopyran-3-yl)pr opionic acid, a small molecule isocoumarin, potentiates dexamethasone-induced apoptosis of human multiple myeloma cells. Cancer Res 64:8512-8516.

Bhattacharyya SS, Paul S, Mandal SK, Banerjee A, Boujedaini N and Khuda-Bukhsh AR (2009) A synthetic coumarin (4methyl-7 hydroxy coumarin) has anti-cancer potentials against DMBA-induced skin cancer in mice. Eur $\mathrm{J}$ Pharmacol 614:128-136.

Borges MFM, Roleira FMF, Milhazes NJSP, Villare EU and Penin LS (2009) Simple coumarins: Privileged scaffolds in medicinal chemistry. In: Reitz AB, Choudhary MI and Atta-ur-Rahman (eds) Frontiers in Medicinal Chemistry. $4^{\text {th }}$ edition. Bentham Science Publisher, Dubai, pp 23-85.

Born SL, Fix AS, Caudill D and Lehman-McKeemam LD (1999) Development of tolerance to Clara cell necrosis with repeat administration of coumarin. Toxicol Sci 51:300-309.

Carvalho PC, Santos EA, Schneider BU, Matuo R, Pesarini JR, Cunha-Laura AL, Monreal AC, Lima DP, Antoniolli AC and Oliveira RJ (2015) Diaryl sulfide analogs of combretastatin A-4: Toxicogenetic, immunomodulatory and apoptotic evaluations and prospects for use as a new chemotherapeutic drug. Environ Toxicol Pharmacol 40:715-721.

Chen JL, Zhu JS, Hong J, Chen MX, Lu JL, Chen WX, Shen B, Zhu ZM and Chen NW (2007) Effect of 2-(8-hydroxy6-methoxy-1-oxo-1H-2-benzopyran-3-yl) propionic acid in combination with carboplatin on gastric carcinoma growth in vivo. World J Gastroenterol 4:509-514.

Curini M, Epifano F, Maltese F, Marcotullio MC, Tubaro A, Altinier G, Gonzales SP and Rodriguez J (2004) Synthesis and anti-inflammatory activity of natural and semisynthetic geranyloxycoumarins. Bioorg Med Chem Lett 14:22412243.

Di Stasi LC, Camuesco D, Nieto A, Vilegas W, Zarzuelo A and Galvez J (2004) Intestinal anti-inflammatory activity of paepalantine, an isocoumarin isolated from the capitula of
Paepalanthus bromelioides, in the trinitrobenzenesulphonic acid model of rat colitis. Planta medica 4:315-320.

Fedel-Miyasato LES, Formagio ASN, Auharek SA, Kassuya CAL, Navarro SD, Cunha-Laura A, Monreal ACD, Vieira MC and Oliveira RJ (2014) Antigenotoxic and antimutagenic effects of Schinus terebinthifolius Raddi in Allium cepa and Swiss mice: A comparative study. Genet Mol Res 13:3411-3425.

Fylaktakidou KC, Hadjipavlou-Litina DJ, Litinas KE and Nicolaides SN (2004) Natural and synthetic coumarin derivatives with anti-inflammatory/antioxidant activities. Curr Pharm Des 10:3813-3833.

Hayashi M, Morita T, Kodama Y, Sofuni T and Ishidate Junior M (1990) Evaluation of chemopreventive activity of glutamine by the comet and the micronucleus assay in mice's peripheral blood. Mutat Res 245:245-249.

Ishii PL, Prado CK, Mauro MO, Carreira CM, Mantovani MS, Ribeiro LR, Dichi JB and Oliveira RJ (2011) Evaluation of Agaricus blazei in vivo for antigenotoxic, anticarcinogenic, phagocytic and immunomodulatory activities. Regul Toxicol Pharmacol 59:412-422.

Kada T, Inoue T and Namiki N (1982) Environmental desmutagens and antidesmutagens. In: Klekowski EJ (ed) Environmental Mutagenesis and Plant Biology. Praeger, New York, pp 137-151.

Kada T and Shimoi K (1987) Desmutagens and bio-antimutagens - Their modes of action. BioEssays 7:113-116.

Kaminskyy D, Kryshchyshyn A, Nektegayev I, Vasylenko O, Grellier P and Lesyk R (2014) Isothiocoumarin-3-carboxylic acid derivatives: Synthesis, anticancer and antitrypanosomal activity evaluation. Eur J Med Chem 75:57-66.

Lacy A and O'Kennedy R (2004) Studies on coumarins and coumarin-related compounds to determine their therapeutic role in the treatment of cancer. Curr Pharm Des 10:37973811.

Lake BG (1984) Investigations into the mechanism of coumarininduced hepatotoxicity in the rat. Arch Toxicol Suppl 7:16-29.

Lake BG (1999) Coumarin metabolism, toxicity and carcinogenicity: Relevance for human risk assessment. Food Chem Toxicol 37:423-453.

Liu XL, Zhang L, Fu XL, Chen K and Qian BC (2001) Effect of scopoletin on PC3 cell proliferation and apoptosis. Acta Pharmacol Sin 22:929-933.

Luchini AC, Rodrigues-Orsi P, Cestari SH, Seito LN, Witaicenis A, Pellizzon CH and Di Stasi LC (2008) Intestinal antiinflammatory activity of coumarin and 4-hydroxycoumarin in the trinitrobenzenesulphonic acid model of rat colitis. Biol Pharm Bull 31:1343-1350.

Manoharan K and Banerjee MR (1985) beta-Carotene reduces sister chromatid exchanges induced by chemical carcinogens in mouse mammary cells in organ culture. Cell Biol Int Rep 9:783-789.

Mauro MO, Sartori D, Oliveira RJ, Ishii PL, Mantovani MS and Ribeiro LR (2011) Activity of selenium on cell proliferation, cytotoxicity, and apoptosis and on the expression of CASP9, BCL-XL and APC in intestinal adenocarcinoma cells. Mutat Res 715:7-12.

Mauro MO, Pesarini JR, Marin-Morales MA, Monreal MTFD, Monreal ACD, Mantovani MS and Oliveira RJ (2014) Evaluation of the antimutagenic activity and mode of action of 
the fructooligosaccharide inulin in the meristematic cells of Allium cepa culture. Genet Mol Res 3:4808-4819.

Melo-Cavalcante AA, Picada JN, Rubensam G and Henriques JA (2008) Antimutagenic activity of cashew apple (Anacardium occidentale Sapindales, Anacardiaceae) fresh juice and processed juice (cajuína) against methyl methanesulfonate, 4-nitroquinoline $\mathrm{N}$-oxide and benzo [a] pyrene. Genet Mol Biol 31:759-766.

Murakami A, Nakamura Y, Tanaka T, Kawabata K, Takahashi D, Koshimizu K and Ohigashi H (2000) Suppression by citrus auraptene of phorbol ester-and endotoxin-induced inflammatory responses: Role of attenuation of leukocyte activation. Carcinogenesis 21:1843-1850.

Napimogaa MH and Yatsuda R (2010) Scientific evidence for Mikania laevigata and Mikania glomerata as a pharmacological tool. J Pharm Pharmacol 62:809-820.

Navarro SD, Beatriz A, Meza A, Pesarini JR, Gomes RS, Karaziack CB, Cunha-Laura AL, Monreal ACD, Romão W, Júnior VL, et al. (2014) A new synthetic resorcinolic lipid 3-Heptyl-3,4,6-trimethoxy-3H-isobenzofuran-1-one: Evaluation of toxicology and ability to potentiate the mutagenic and apoptotic effects of cyclophosphamide. Eur J Med Chem 75:132-142.

Nishiyama T, Ohnishi J and Hashiguchi Y (2001) Fused heterocyclic antioxidants: Antioxidative activities of hydrocoumarins in a homogeneous solution. Biosci Biotechnol Biochem 65:1127-1133.

Oliveira RJ, Ribeiro LR, Silva AF, Matuo R and Mantovani MS (2006) Evaluation of antimutagenic activity and mechanisms of action of beta-glucan from barley, in CHO-k1 and HTC cell lines using the micronucleus test. Toxicol in Vitro 20:1225-1233.

Oliveira RJ, Matuo R, Silva AF, Matiazi HJ, Mantovani MS and Ribeiro LS (2007) Protective effect of beta-glucan extracted from Saccharomyces cerevisiae, against DNA damage and cytotoxicity in wild-type $(\mathrm{k} 1)$ and repair-deficient (xrs5) CHO cells. Toxicol In Vitro 21:41-52.

Oliveira RJ, Salles MJ, Silva AF, Kanno TY, Lourenço AC, Freiria GA, Matiazi HJ, Ribeiro LR and Mantovani MS (2009a) Effects of the polysaccharide beta-glucan on clastogenicity and teratogenicity caused by acute exposure to cyclophosphamide in mice. Regul Toxicol Pharmacol 53:164-173.

Oliveira RJ, Baise E, Mauro MO, Pesarini JR, Matuo R, Silva AF, Ribeiro LR and Mantovani MS (2009b) Evaluation of chemopreventive activity of glutamine by the comet and the micronucleus assay in mice's peripheral blood. Environ Toxicol Pharmacol 28:120-124.

Oliveira RJ, Salles MJS, Silva AF, Kanno TYN, Lourenço ACS, Leite VS, Matiazi HJ, Pesarini JR, Ribeiro LR and Mantovani MS (2013) In vivo evaluation of the antimutagenic and antigenotoxic effects of $\beta$-glucan extracted from Saccharomyces cerevisiae in acute treatment with multiple doses. Genet Mol Biol 36:413-424.

Oliveira RJ, Pesarini JR, Salles MJS, Kanno TYN, Lourenço ACS, Leite VS, Silva AF, Matiazi HJ, Ribeiro LR and Mantovani MS (2014) Effects of $\beta$-glucan polysaccharide revealed by the dominant lethal assay and micronucleus assays, and reproductive performance of male mice exposed to cyclophosphamide. Genet Mol Biol 37:111-119.

Pal S, Chatare V and Pal M (2011) Isocoumarin and its derivatives: An overview on their synthesis and applications. Curr Org Chem 15:782-800.

Parikka K, Rowland IR, Welch RW and Wähälä K (2006) In vitro antioxidant activity and antigenotoxicity of 5-n-alkylresorcinols. J Agr Food Chem 54:1646-1650.

Paya M, Goodwin PA, De Las Heras B and Hoult JR (1994) Superoxide scavenging activity in leukocytes and absence of cellular toxicity of a series of coumarins. Biochem Pharmacol 48:445-451.

Queiroz MRP, Calhelha RC, Vale-Silva LA, Pinto E and Nascimento MSJ (2009) Synthesis of novel 3-(aryl)benzothieno[2,3-c]pyran-1-ones from Sonogashira products and intramolecular cyclization: Antitumoral activity evaluation. Eur J Med Chem 44:1893-1899.

Rasmussen L and Arvin A (1982) Chemotherapy-induced immunosuppression. Environ Health Perspect 43:21-25.

Rovozzo G and Burke CN (1973) Manual of Basic Virological Techniques. Prentice Hall, New Jersey, 287 p.

Shokoohinia Y, Hosseinzadeh L, Alipour M, Mostafaie A and Mohammadi-Motlagh HR (2014) Comparative evaluation of cytotoxic and apoptogenic effects of several coumarins on human cancer cell lines: Osthole induces apoptosis in p53-deficient H1299 cells. Adv Pharmacol Sci 2014:847574.

Stasiuk M and Kozubek A (2010) Biological activity of phenolic lipids. Cell Mol Life Sci 67:841-860.

Subramanian V, Batchu VR, Barange D and Pal M (2005) Synthesis of isocoumarins via $\mathrm{Pd} / \mathrm{C}$-mediated reactions of o-iodobenzoic acid with terminal alkynes. J Org Chem 70:47784783.

Vukicevic V, Kampfinger K and Stopper H (2004) Influence of altered apoptosis in human lymphoblastoid cell lines on micronucleus frequency. Toxicol Lett 147:187-195.

Waters MD, Brady AL, Stack HF and Brockman HE (1990) Antimutagenicity profiles for some model compounds. Mutat Res 238:57-85.

Yin L, Ohno T, Weichselbaum R, Kharbanda S and Kufe D (2001) The novel isocoumarin 2-(8-hydroxy-6-methoxy-1oxo-1H-2-benzopyran-3-yl) propionic acid (NM-3) induces lethality of human carcinoma cells by generation of reactive oxygen species. Mol Cancer Ther 1:43-48.

Yourick JJ and Bronaugh RL (1997) Percutaneous absorption and metabolism of coumarin in human and rat skin. J Appl Toxicol 3:153-158.

Zhang L, Jiang G, Yao F, He Y, Liang G, Zhang Y, Hu B, Wu Y, Li Y and Liu H (2012) Growth inhibition and apoptosis induced by osthole, a natural coumarin, in hepatocellular carcinoma. PLoS One 7:e37865.

Associate Editor: Daisy Maria Fávero Salvadori

License information: This is an open-access article distributed under the terms of the Creative Commons Attribution License (type CC-BY), which permits unrestricted use, distribution and reproduction in any medium, provided the original article is properly cited. 